\title{
Crosstalk between purinergic receptors and lipid mediators in leishmaniasis
}

\author{
Mariana M. Chaves ${ }^{1,2,3}$, Cláudio Canetti ${ }^{2,3}$ and Robson Coutinho-Silva ${ }^{1,3^{*}}$
}

\begin{abstract}
Leishmaniasis is a neglected tropical disease affecting millions of people around the world caused by organisms of the genus Leishmania. Parasite escape mechanisms of the immune system confer the possibility of resistance and dissemination of the disease. A group of molecules that has become a target for Leishmania survival strategies are lipid mediators. Among them, leukotriene $\mathrm{B}_{4}\left(\mathrm{LTB}_{4}\right)$ has been described as a pro-inflammatory molecule capable of activating cells of the immune system to combat Leishmania. In an opposite way, prostaglandin $E_{2}\left(P_{G} E_{2}\right)$ is a lipid mediator described as a deactivator of macrophages and neutrophils. The balance of these two molecules can be generated by extracellular nucleotides, such as adenosine 5'-triphosphate (ATP) and adenosine (Ado), which activate the purinergic receptors system. Herein, we discuss the role of extracellular nucleotides and the resulting balance of $\mathrm{LTB}_{4}$ and $\mathrm{PGE} \mathrm{E}_{2}$ in Leishmania fate, survival or death.

Abbreviations: ATP, 5'-adenosine triphosphate; eATP, extracellular ATP; Ado, Adenosine; DC, Dermal dendritic cells; LCs, Langerhans cells; LPG, Lipophosphoglyca; GP63, Glycoprotein 63; CR, Complement receptor; MR, Mannose receptor; FcyRs, Fc gamma receptors; FNRS, Fibronectin receptors; TLR, Toll-like receptor; DAMP, Damage-associated molecular pattern; cytosolic phospholipase A2; COX, Cicloxygenase; 5-LO, 5-lipoxygenase; LTB 4 , Leukotriene B ${ }_{4}$; $\mathrm{NO}$, Nitric oxide; ROS, Reactive oxygen species; $\mathrm{PGE}_{2}$, Prostaglandin $\mathrm{E}_{2} ; \mathrm{AMP}, 5^{\prime}$-adenosine mono-phosphate; TNF, Tumor necrosis factor; UTP, Uridine triphosphate; PAMPs, Pathogen-associated molecular patterns
\end{abstract}

\section{Review}

\section{Background}

The protozoan parasites of the genus Leishmania cause a broad range of human diseases called leishmaniasis. Leishmaniasis is a neglected disease of tropical and subtropical areas that affects more than 12 million people worldwide [1]. Moreover, every year, 2 million new cases are diagnosed, among them, $75 \%$ of the cases are cutaneous and $25 \%$ are visceral leishmaniasis, leading to it being the second most common cause of parasiteassociated death resulting in 20,000 to 30,000 deaths per year [2]. Leishmania preferentially infect phagocytic cells, as macrophages, neutrophils and dendritic cells of susceptible mammalian hosts [3] causing numerous clinical manifestations. In general, cutaneous leishmaniasis

\footnotetext{
* Correspondence: rcsilva@biof.ufri.br

${ }^{1}$ Laboratory of Immunophysiology, Biophysics Institute Carlos Chagas Filho,

Federal University of Rio de Janeiro, Rio de Janeiro, RJ 21941-902, Brazil

${ }^{3}$ National Institute of Translational Research in Health and Environment in the Amazon Region, Biophysics Institute Carlos Chagas Filho, Federal

University of Rio de Janeiro, Rio de Janeiro, RJ 21941-902, Brazil

Full list of author information is available at the end of the article
}

is located adjacent to the infectious site, the skin or lymph nodes. The parasite can escape into the nasal and oropharyngeal mucosa causing mucocutaneous leishmaniasis; or also migrate to the spleen, liver, bone marrow, and distant lymph nodes, leading to lethal clinical manifestations, named visceral leishmaniasis or kala-azar [4].

Leishmaniasis is transmitted by a female bloodsucking insects of the genus Phlebotomus in the 'Old' World and by species of Lutzomya in the 'New' World. The parasite can occur in two ways: the promastigote, which has high mobility, and is found in the digestive tract of the vector; and amastigote, without flagella, which develops into the phagolysosomes of phagocytic cells. Immediately before blood intake, the insect saliva containing promastigote forms is inoculated into the skin of the mammalian host. Soon after, the parasite is phagocytosed, remaining viable inside the phagolysosome, the fused phagosome and lysosome. Then, the promastigote form differentiates in amastigote approximately $12-24 \mathrm{~h}$ later $[5,6]$. When an infected mammal host is bitten by the sand fly, it sucks amastigote- 
infected macrophages or free amastigotes which will transform into mobile flagellated promastigotes in the midgut of the vector. In this process, procyclic promastigotes (proliferative and non-infective forms) acquire the ability to be virulent and non-proliferative, the metacyclic promastigotes, and this process is called metacyclogenesis [7]. These promastigote forms migrate to the oral cavity promoting the transmission in the next blood meal.

The innate immune cells present in the skin are the first line of defense against Leishmania infection [8]. Dermal dendritic cells (DCs), Langerhans cells (LCs) [9, 10], mast cells, $\mathrm{T}$ cells, and macrophages are the immune cells in the skin. Interesting, keratinocytes, which are the most abundant in the skin, also play an active role in the local immune response and it has been reported that they have an important role in polarization of the Th1 response during leishmaniasis $[11,12]$. After parasite inoculum into the dermis, neutrophils quickly infiltrate and phagocytose Leishmania parasites, becoming the first circulatory cells to reach tissue space [13-15]. Macrophages are the second wave of infiltrating immune cells and are the principal host cells for the Leishmania $[16,17]$. Thus, neutrophils and macrophages play crucial roles in disease progression, but ironically as professional phagocytic and killing cells, they become targets because of evasion mechanisms employed by Leishmania to subvert the host immune system.

Macrophages and neutrophils possess several pattern recognition receptors (PRR) that respond to pathogenassociated molecular patterns (PAMPs) present in the Leishmania surface, such as lipophosphoglycan (LPG) and glycoprotein 63 (GP63), both in humans and in mice [18-21]. Several host immune receptors can bind Leishmania components or antibodies against Leishmania, such as: the first and third complement receptor (CR1 and CR3, respectively) [22, 23], mannose receptor (MR) [24, 25], Fc gamma receptors (Fc $\gamma \mathrm{Rs})$ [26], fibronectin receptors (FNRS) [18], and Toll-like receptors (TLR) [27-30]. TLRs are phylogenetically the most ancient and best studied PRRs. In humans, 10 TLR family members have been identified and there are 12 in mice [31]. TLRs activation has been associated with the production and release of inflammatory mediators, such as cytokines, lipid mediators, and adenosine 5 '-triphosphate (ATP) in extracellular medium [32-34]. ATP is widely present in the intracellular environment, at concentrations in the millimolar range, whereas it is almost imperceptible in the extracellular space, being around nanomolar [35]. We recently showed that Leishmania amazonensis recognition by macrophages leads to ATP release [36] (Fig. 1a). However, the receptor involved in this release and the mechanism that triggers this process has not yet been elucidated.

\section{Purinergic receptors}

Extracellular ATP (eATP) is defined as a damageassociated molecular pattern (DAMP) causing biological effects though the activation of purinergic receptors that are presented on the cell membrane. Purinergic receptors are classified into two large families: P1 and P2. The P1 receptor family is characterized by metabotropic receptors activated by adenosine: $\mathrm{A} 1, \mathrm{~A} 2_{\mathrm{a}}, \mathrm{A} 2_{\mathrm{b}}$, and $\mathrm{A} 3$ [37]. The P1 receptor activation has been discussed in several systems, suggesting a role in both physiological and pathological processes. In the immune system, P1 receptors are widely expressed by cells of the myeloid and lymphoid lineage [38]. P1 receptors act in regulating the immune response, and are involved mainly in resolving inflammation [39].

The P2 family of receptors is subdivided into P2X and P2Y. The P2Y receptors are G-protein coupled receptors, [35] while P2X are ionotropic receptors, capable of forming cationic channels activated by eATP. The participation of P2Y receptors in inflammatory events has been described [40, 41]. Furthermore, it has been reported that P2Y2 receptors act in neutrophil chemotaxis after activation by eATP [42]. The family of P2X receptors, in contrast, consists of ionotropic receptors. These receptors are intrinsic ion channels for $\mathrm{Na}^{+}, \mathrm{K}^{+}$, and $\mathrm{Ca}^{2+}$. To date, seven subtypes of P2X family have been cloned: P2X1 to P2X7 [43, 44]. The most studied of $\mathrm{P} 2 \mathrm{X}$ receptors is the $\mathrm{P} 2 \mathrm{X} 7$ subtype. This receptor has two transmembrane domains, being a polypeptide of 595 amino acids with a longer $\mathrm{C}$-terminal domain, compared to other members of the P2X family. This peculiarity makes it capable of inducing the formation of pores permeable to molecules up to 900 Daltons after sustained eATP stimulation [45]. Moreover, the elongated Cterminal enables it to initiate various intracellular signaling cascades culminating with apoptosis, vesicular fusion, phospolipase D activation, exosome release, activation and secretion of pro-inflammatory cytokines IL$1 \beta$ and IL-18 [44]. The expression of P2X7 receptor is well characterized under many cell types, including macrophages [46], monocytes [47], neutrophils [48], among others [49]. Furthermore, many studies have demonstrated the participation of purinergic receptors in the induction of bioactive lipid mediators [50-54].

\section{Lipid mediators}

Lipid metabolites of arachidonic acid (AA), including leukotrienes (LTs) and prostaglandins (PGs), have emerged as important mediators of a variety of physiological and pathophysiological functions. They are synthesized through the metabolism of AA released by cytosolic phospholipase $\mathrm{A}_{2}$. The lipid metabolites can be subsequently metabolized by different pathways, including the cycloxygenase (COX) enzymes and lipoxygenase 


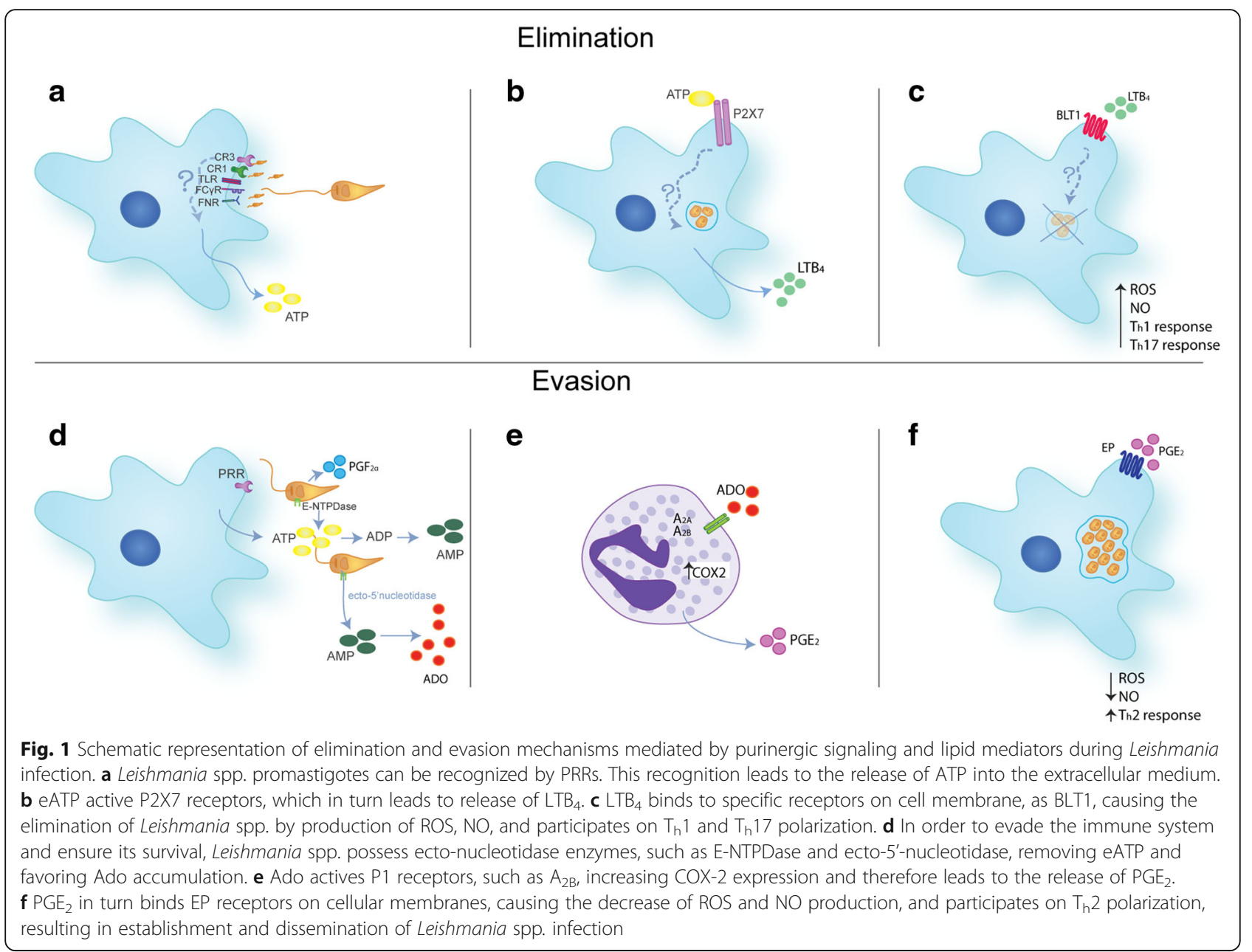

(LO) generating a range of bioactive eicosanoids, named PGs and LTs, respectively. The activation of $\mathrm{CPLA}_{2}$ and 5LO involves an increase of intracellular $\mathrm{Ca}^{2+}$ and subsequently activation of certain protein kinases, as well as translocation of 5-LO from cytoplasm and nucleoplasm to membrane sites such as the nuclear envelope [55]. The AA is presented to 5-LO by an essential accessory protein called 5-LO activating protein (FLAP), producing an unstable precursor of all other leukotrienes, the $\mathrm{LTA}_{4}$ [55]. Once generated, $\mathrm{LTA}_{4}$ can be conjugated with reduced glutathione by $\mathrm{LTC}_{4}$ synthase $\left(\mathrm{LTC}_{4} \mathrm{~S}\right)$ to form $\mathrm{LTC}_{4}$, or $\mathrm{LTA}_{4}$ can also be hydrolyzed by $\mathrm{LTA}_{4}$ hydrolase $\left(\mathrm{LTA}_{4} \mathrm{H}\right)$ to form $\mathrm{LTB}_{4}$ [56]. $\mathrm{LTC}_{4}$ as $\mathrm{LTB}_{4}$ can be exported to the extracellular space through specific transporters [57-59]. In the extracellular environment, $\mathrm{LTC}_{4}$ is rapidly converted to $\mathrm{LTD}_{4}$ by the glutamyl leukotrienase removing glutamic acid molecule of $\mathrm{LTC}_{4}$, and $\mathrm{LTD}_{4}$ can be further converted to $\mathrm{LTE}_{4}$ by the dipeptidase which removes a glycine residue of $\mathrm{LTD}_{4}$ molecule [60]. $\mathrm{LTB}_{4}$ is best known as a chemotactic and activator for leukocytes, and cysteinyl leukotrienes $\left(\mathrm{LTC}_{4}, \mathrm{LTD}_{4}\right.$, and $\left.\mathrm{LTE}_{4}\right)$ are widely known in the pathogenesis of asthma [61].
PGs are formed when AA is metabolized by sequential actions of cyclooxygenase and their specific synthases [62]. COX has both cyclooxygenase (COX) and peroxidase activity, and three COX isoforms were described: COX-1, COX-2 and COX-3 [63, 64]. COX-1 and COX-3 are constitutively expressed while COX-2 is induced by inflammatory stimuli $[64,65]$. There are six bioactive PGs: $\mathrm{PGE}_{2}, \mathrm{PGI}_{2}, \mathrm{PGD}_{2}$ and $\mathrm{PGF}_{2}$ [62]. Much is known about the pro-inflammatory functions of PGs, but, in the past years, it has been proven to also possess potential anti-inflammatory effects of PGs observed in resolution phase [66], and, importantly, these effects can be used by parasites to evade the immune system.

\section{Purinergic receptor, lipid mediators and immune evasion}

The most effective mechanisms against infection by Leishmania already described involve the production of reactive oxygen species (ROS) and nitric oxide (NO) [67]. Furthermore, it has been shown that an effective response against infection by Leishmania is given by the induction of $T_{h} 1$ and $T_{h} 17$ responses [68-72], while $T_{h} 2$ response promotes susceptibility $[68,70]$. 
The role of extracellular nucleotides and the activation of purinergic receptors during infection by L. amazonensis have been investigated [73]. Marques-da-Silva and colleagues [74] showed that P2Y2 and P2Y4 receptors have its expression upregulated and increased levels of uridine triphosphate (UTP) nucleotide into the extracellular environment during infection can lead to death of the macrophage by apoptosis and the elimination of the parasite. Other studies have shown that eATP can lead to the elimination of L. amazonensis in infected macrophages via P2X7 receptor [75]. A recent study demonstrates that elimination of $L$. amazonensis by P2X7 receptor depends on the production of $\mathrm{LTB}_{4}$ and leukotriene $\mathrm{B}_{4}$ receptor 1 (BLT1) [36] (Fig. 1b, c). Additionally, other studies have demonstrated the production of $\mathrm{LTB}_{4}$ in resistance to L. amazonensis and L. braziliensis, in humans and mice [76-78]. Furthermore, latest studies have demonstrated the participation of $15 \mathrm{~d}$ Prostaglandin J2 in L. donovani elimination [79]. This resistance can be due to the production of ROS and NO, which may be produced after P2X7 receptor activation $[80,81]$ and $\mathrm{LTB}_{4}$ release [82-85]. Moreover, the $\mathrm{P} 2 \mathrm{X} 7$ receptor activation and $\mathrm{LTB}_{4}$ release have been implicated in the polarization of $T_{h} 1$ and $T_{h} 17$ responses, participating in the immune response against Leishmania [86-90] (Fig. 1c).

Regarding the participation of lipid mediators in Leishmania infection, the role of $\mathrm{PGE}_{2}$ in susceptibility has been discussed. It is known that $\mathrm{PGE}_{2}$ possesses antiinflammatory activity, facilitating Leishmania infection in macrophages, suppressing inflammatory response in both cutaneous and visceral leishmaniasis [91-94]. Moreover, reinforcing the context of a beneficial effect of $\mathrm{PGE}_{2}$ for Leishmania survival, it was demonstrated that several Leishmania species possess lipid corpuscles as organelles and L. infantum is able to produce and release PGs, such as $\mathrm{PGF}_{2 \alpha}$ itself $[95,96]$ (Fig. 1d). It is important to highlight that $\mathrm{PGE}_{2}$ inhibits $\mathrm{NO}$ production [97], and $T_{h} 1$ and $T_{h} 17$ development [98-101] and, consequently, stimulates $\mathrm{T}_{\mathrm{h}} 2$ response, favoring infection [99] (Fig. 1f).

On the other hand, in order to perpetuate itself, Leishmania has developed methods to subvert microbicidal mechanisms and immune responses against itself. As already described before, eATP has proved to be an endogenous molecule able to induce the death of $L$. amazonensis through $\mathrm{P} 2 \mathrm{X} 7$ receptors activation [36]. It has also been well established that the presence of enzymes capable of degrading ATP in the mammalian cell membrane forming ADP (adenosine-diphosphate) and adenosine (Ado), named ecto-nucleotidases. Among them, CD39 (ecto-NPTDase) and CD73 (ecto-5' -nucleotidase) exert relevant actions, regulating inflammatory responses of ATP and UTP. Thus, Ado is formed through the action of CD39 that converts ATP and ADP to 5'-adenosine mono-phosphate (AMP). AMP is the substrate for CD73. This enzyme, in turn, catalyzes the reaction that converts AMP to Ado $[39,102]$. In this scenario, it has been shown that Leishmania express ectonucleotidase activity. This is confirmed by the observation of increased Ado levels in serum from visceral leishmaniasis patients $[103,104]$. This can cause the prevention of the activation of macrophages and leads to the increase of infection by Leishmania species [105109]. Moreover, the virulence of $L$. amazonensis promastigotes could be due to its high ecto-nucleotidase activity [110] (Fig. 1d). Moreover, ecto-5-nucleotidase activity also has been seen in L. chagasi [105]. Furthermore, it has been observed that $L$. amazonensis infection increases ecto-nucleotidases expression in DC [111]. Thus, the blocking of the $A_{2 B}$ receptors is found to increase production of $\mathrm{NO}$ and decrease parasite survival, suggesting participation of Ado in this process [109].

Others have shown that Ado increases COX-2 expression and $\mathrm{PGE}_{2}$ production in neutrophils [112, 113] (Fig. 1e). This corroborates the fact that both Ado and $\mathrm{PGE}_{2}$ stimulates the release of anti-inflammatory cytokines, such as interleukin (IL)-10 in macrophages [114, $115]$, while inhibiting the release of pro-inflammatory cytokines, such as tumor necrosis factor (TNF)- $\alpha$ and IL-12 in DCs and macrophages $[116,117]$. This stimulates an anti-inflammatory environment, allowing establishment of infection.

It has been shown that Ado decreases production and release of $\mathrm{LTB}_{4}$ [118-121], which modulates microbicidal mechanisms. Moreover, it is known that L. amazonensis is capable to negatively modulate the production of $\mathrm{LTB}_{4}$ via $\mathrm{P} 2 \mathrm{X} 7$ receptor activation in macrophages from $\mathrm{C} 57 \mathrm{BL} / 6$ and BALB/C mice [36]. Neutrophils are recruited to the infection site when infection is initiated by sand fly bite $[14,122]$, spreading Leishmania parasites $[17,123,124]$. However, in other species of Leishmania, such as L. braziliensis, the neutrophils are important for parasite elimination [125]. Nevertheless, the role of the Ado in stimulation of $\mathrm{PGE}_{2}$ production in macrophages still needs to be studied. Moreover, other pathogens use Ado to subvert the immune system such as Toxoplasma gondii, Staphylococcus aureus and Streptococcus agalactiae [126-128].

The role of sand fly saliva substances in modulating Leishmania infection has been demonstrated [129, 130]. Furthermore, it has been described that sand fly saliva can inhibit NO production, and consequently increase the parasite load [131, 132]. It has also been described that Lutzomyia longipalpis saliva possesses ATPase activity, which can hydrolyse eATP [133]. Sand fly saliva also contains high levels of Ado, modulating the inflammatory micro-environment, causing NO inhibition, and 

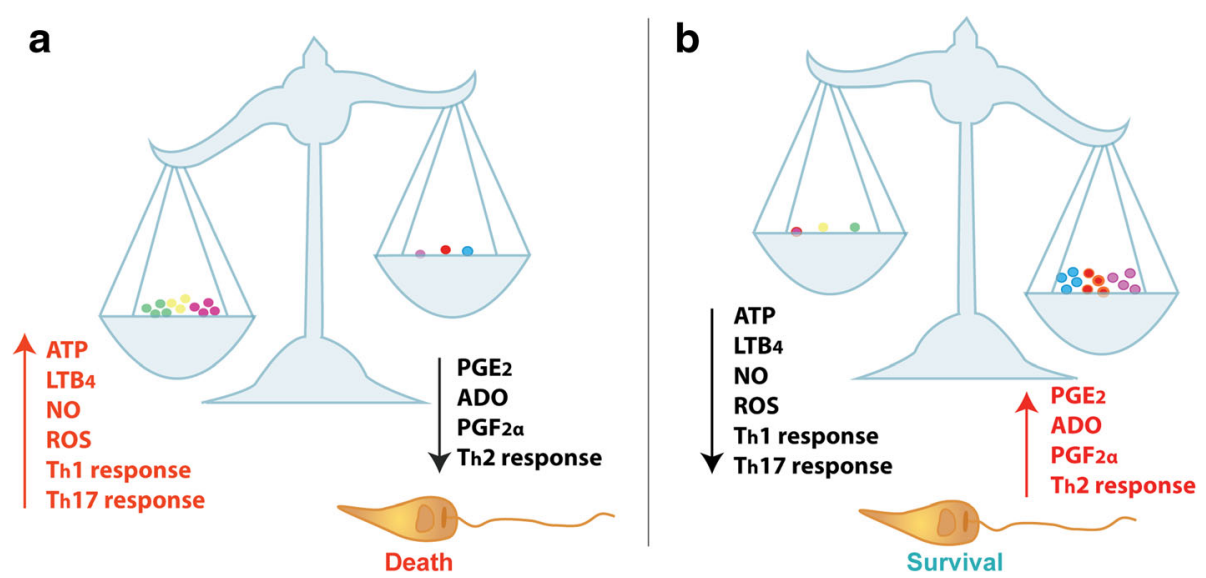

Fig. 2 Balance between nucleotides and inflammatory lipid mediators on Leishmania spp. infection establishment. a The increase of ATP and reduction of Ado in extracellular medium leads to an overproduction of $\mathrm{LTB}_{4}$, which in turn stimulates the production of ROS and NO, and the polarization of immune responses for a $T_{h} 1$ and $T_{h} 17$ pattern; meanwhile a high $P G E_{2}$ production also directs the polarization for $T_{h} 2$ response. This scenario facilitates the elimination of Leishmania spp. by macrophages. $\mathbf{b}$ The evasion of Leishmania spp. occurs when Ado concentrations in the extracellular medium overlaps the ATP. Thus, there is an increase in $\mathrm{PGE}_{2}$ and decreased ROS and NO, with consequent polarization $T_{h} 2$

macrophage inactivation, which in turn increases the parasitic load in macrophages and neutrophils [134136]. Recently it was shown that exosomes are coinoculated with Leishmania into mammalian hosts [137]. It is tempting to correlate it with a burst of ATP secretion, local Ado generation and $\mathrm{PGE}_{2}$ production. It is known that $L$. longipalpis saliva triggers the production and release of $\mathrm{PGE}_{2}$ and decreases $\mathrm{LTB}_{4}$ in macrophages $[138,139]$.

\section{Conclusion}

The establishment of Leishmania infection can be due to the balance of several factors. Extracellular nucleotides can modulate the balance of pro- and anti-inflammatory factors such as PGs and LTs. To ensure their survival, Leishmania spp. developed strategies throughout its evolution to guarantee its perpetuation (Fig. 2a). The ability of Leishmania spp. to modulate extracellular concentrations of ATP and Ado, and consequently the balance of $\mathrm{LTB}_{4}$ and $\mathrm{PGE}_{2}$ shows how organisms can subvert the immune system of the host (Fig. 2b). Thus, the importance of knowledge of these strategies of evasion is essential in order to develop drugs capable to counterbalance Leishmania evasion.

\section{Acknowledgments}

We thank Ludmilla Dellatorre for help in preparing the figures, Dr Larry Johnson for revision of English language and CNPq, CAPES and FAPERJ for financial support.

\section{Funding}

This work was supported by the Conselho Nacional de Deselvimento Científico e Tecnológico (CNPq), Coordenação de Aperfeiçoamento de Nível Superior (CAPES) and Fundação de Amparo à Pesquisa do Estado do Rio de Janeiro (FAPERJ) (grant number E-26/111.182/2011).
Availability of data and material

Not applicable.

\section{Authors' contributions}

MMC carried out the literature search, prepared the draft of the manuscript and wrote the paper. CC contributed to writing the paper and critically revised the manuscript. RCS contributed to writing the paper and critically revised the manuscript. All authors read and approved the final manuscript.

\section{Consent for publication}

Not applicable.

Ethics approval and consent to participate Not applicable.

\section{Disclosures}

The authors have no financial conflicts of interest.

\section{Author details}

'Laboratory of Immunophysiology, Biophysics Institute Carlos Chagas Filho, Federal University of Rio de Janeiro, Rio de Janeiro, RJ 21941-902, Brazil. ${ }^{2}$ Laboratory of Inflammation, Biophysics Institute Carlos Chagas Filho, Federal University of Rio de Janeiro, Rio de Janeiro, RJ 21941-902, Brazil. ${ }^{3}$ National Institute of Translational Research in Health and Environment in the Amazon Region, Biophysics Institute Carlos Chagas Filho, Federal University of Rio de Janeiro, Rio de Janeiro, RJ 21941-902, Brazil.

Received: 27 January 2016 Accepted: 29 August 2016

Published online: 05 September 2016

\section{References}

1. Desjeux P. Leishmaniasis: current situation and new perspectives. Comp Immunol Microbiol Infect Dis. 2004;27(5):305-18.

2. Alvar J, Velez ID, Bern C, Herrero M, Desjeux P, Cano J, et al. Leishmaniasis worldwide and global estimates of its incidence. PLoS One. 2012;7(5): e35671.

3. van GJ, Diro E. Visceral leishmaniasis. Infect Dis Clin North Am. 2012;26(2): 309-22.

4. Murray HW, Berman JD, Davies CR, Saravia NG. Advances in leishmaniasis. Lancet. 2005;366(9496):1561-77.

5. Courret N, Frehel C, Prina E, Lang T, Antoine JC. Kinetics of the intracellular differentiation of Leishmania amazonensis and internalization of host MHC molecules by the intermediate parasite stages. Parasitology. 2001;122(Pt 3): 263-79. 
6. Galvao-Quintao L, Alfieri SC, Ryter A, Rabinovitch M. Intracellular differentiation of Leishmania amazonensis promastigotes to amastigotes: presence of megasomes, cysteine proteinase activity and susceptibility to leucine-methyl ester. Parasitology. 1990;101(Pt 1):7-13.

7. da Silva R, Sacks DL. Metacyclogenesis is a major determinant of Leishmania promastigote virulence and attenuation. Infect Immun. 1987:55(11):2802-6.

8. Solbach W, Laskay T. The host response to Leishmania infection. Adv Immunol. 2000;74:275-317.

9. Merad M, Ginhoux F, Collin M. Origin, homeostasis and function of Langerhans cells and other langerin-expressing dendritic cells. Nat Rev Immunol. 2008;8(12):935-47.

10. Nestle FO, Di MP, Qin JZ, Nickoloff BJ. Skin immune sentinels in health and disease. Nat Rev Immunol. 2009:9(10):679-91.

11. Albanesi C, Scarponi C, Giustizieri ML, Girolomoni G. Keratinocytes in inflammatory skin diseases. Curr Drug Targets Inflamm Allergy. 2005;4(3): 329-34

12. Ehrchen JM, Roebrock K, Foell D, Nippe N, von SE, Weiss JM, et al. Keratinocytes determine Th1 immunity during early experimental leishmaniasis. PLoS Pathog. 2010;6(4):e1000871.

13. Beil WJ, Meinardus-Hager G, Neugebauer DC, Sorg C. Differences in the onset of the inflammatory response to cutaneous leishmaniasis in resistant and susceptible mice. J Leukoc Biol. 1992;52(2):135-42.

14. Peters NC, Egen JG, Secundino N, Debrabant A, Kimblin N, Kamhawi S, et al. In vivo imaging reveals an essential role for neutrophils in leishmaniasis transmitted by sand flies. Science. 2008;321(5891):970-4.

15. Ribeiro-Gomes FL, Sacks D. The influence of early neutrophil-Leishmania interactions on the host immune response to infection. Front Cell Infect Microbiol. 2012:2:59.

16. Ribeiro-Gomes FL, Otero AC, Gomes NA, Moniz-De-Souza MC, CysneFinkelstein L, Arnholdt AC, et al. Macrophage interactions with neutrophils regulate Leishmania major infection. J Immunol. 2004;172(7):4454-62.

17. van ZG, Klinger M, Mueller A, Dannenberg S, Gebert A, Solbach W, et al. Cutting edge: neutrophil granulocyte serves as a vector for Leishmania entry into macrophages. J Immunol. 2004;173(11):6521-5.

18. Brittingham A, Chen G, McGwire BS, Chang KP, Mosser DM. Interaction of Leishmania gp63 with cellular receptors for fibronectin. Infect Immun. 1999; 67(9):4477-84

19. Vargas-Inc, Tai W, Xin L, Hogg AE, Corry DB, Soong L. Distinct roles for MyD88 and Toll-like receptor 2 during Leishmania braziliensis infection in mice. Infect Immun. 2009;77(7):2948-56.

20. Isnard A, Shio MT, Olivier M. Impact of Leishmania metalloprotease GP63 on macrophage signaling. Front Cell Infect Microbiol. 2012;2:72

21. Spath GF, Garraway LA, Turco SJ, Beverley SM. The role(s) of lipophosphoglycan (LPG) in the establishment of Leishmania major infections in mammalian hosts. Proc Natl Acad Sci U S A. 2003;100(16): 9536-41.

22. Peters $C$, Aebischer $T$, Stierhof $Y D$, Fuchs M, Overath $P$. The role of macrophage receptors in adhesion and uptake of Leishmania mexicana amastigotes. J Cell Sci. 1995:108(Pt 12):3715-24.

23. Kedzierski L, Montgomery J, Bullen D, Curtis J, Gardiner E, Jimenez-Ruiz A, et al. A leucine-rich repeat motif of Leishmania parasite surface antigen 2 binds to macrophages through the complement receptor 3. J Immunol. 2004:172(8):4902-6.

24. Blackwell JM, Ezekowitz RA, Roberts MB, Channon JY, Sim RB, Gordon S. Macrophage complement and lectin-like receptors bind Leishmania in the absence of serum. J Exp Med. 1985;162(1):324-31.

25. Akilov OE, Kasuboski RE, Carter CR, McDowell MA. The role of mannose receptor during experimental leishmaniasis. J Leukoc Biol. 2007;81(5):1188-96.

26. Kima PE, Constant SL, Hannum L, Colmenares M, Lee KS, Haberman AM, et al. Internalization of Leishmania mexicana complex amastigotes via the FC receptor is required to sustain infection in murine cutaneous leishmaniasis. J Exp Med. 2000;191(6):1063-8.

27. Kropf P, Freudenberg N, Kalis C, Modolell M, Herath S, Galanos C, et al. Infection of $\mathrm{C} 57 \mathrm{BL} / 10 \mathrm{SCCr}$ and $\mathrm{C57BL} / 10 \mathrm{SCNCr}$ mice with Leishmania major reveals a role for Toll-like receptor 4 in the control of parasite replication. J Leukoc Biol. 2004;76(1):48-57.

28. Whitaker SM, Colmenares M, Pestana KG, McMahon-Pratt D. Leishmania pifanoi proteoglycolipid complex P8 induces macrophage cytokine production through Toll-like receptor 4. Infect Immun. 2008;76(5):2149-56.

29. Cezario GA, de Oliveira LR, Peresi E, Nicolete VC, Polettini J, de Lima CR, et al. Analysis of the expression of toll-like receptors 2 and 4 and cytokine production during experimental Leishmania chagasi infection. Mem Inst Oswaldo Cruz. 2011:106(5):573-83.

30. Srivastava S, Pandey SP, Jha MK, Chandel HS, Saha B. Leishmania expressed lipophosphoglycan interacts with Toll-like receptor (TLR)-2 to decrease TLR9 expression and reduce anti-leishmanial responses. Clin Exp Immunol. 2013:172(3):403-9.

31. Kawai T, Akira S. The role of pattern-recognition receptors in innate immunity: update on Toll-like receptors. Nat Immunol. 2010;11(5):373-84.

32. Cohen M, Volpin G, Meir T, Klein E, Katz R, Assaf M, et al. Possible association of Toll-like receptor 9 polymorphisms with cytokine levels and posttraumatic symptoms in individuals with various types of orthopaedic trauma: early findings. Injury. 2013;44(11):1625-9.

33. Park JA, Kim Y. Eicosanoid biosynthesis is activated via Toll, but not Imd signal pathway in response to fungal infection. J Invertebr Pathol. 2012; 110(3):382-8.

34. Ren $H$, Teng $Y$, Tan B, Zhang $X$, Jiang $W$, Liu $M$, et al. Toll-like receptortriggered calcium mobilization protects mice against bacterial infection through extracellular ATP release. Infect Immun. 2014;82(12):5076-85.

35. Burnstock G. Physiology and pathophysiology of purinergic neurotransmission. Physiol Rev. 2007;87(2):659-797.

36. Chaves MM, Marques-da-Silva C, Monteiro AP, Canetti C, Coutinho-Silva R. Leukotriene B4 modulates $\mathrm{P} 2 \mathrm{X} 7$ receptor-mediated Leishmania amazonensis elimination in murine macrophages. J Immunol. 2014;192(10):4765-73.

37. Fredholm BB, IJzerman AP, Jacobson KA, Klotz KN, Linden J. International Union of Pharmacology. XXV. Nomenclature and classification of adenosine receptors. Pharmacol Rev. 2001:53(4):527-52.

38. Di VF, Vuerich M. Purinergic signaling in the immune system. Auton Neurosci. 2015:191:117-23.

39. Hasko G, Linden J, Cronstein B, Pacher P. Adenosine receptors: therapeutic aspects for inflammatory and immune diseases. Nat Rev Drug Discov. 2008; 7(9):759-70.

40. Santiago-Perez LI, Flores RV, Santos-Berrios C, Chorna NE, Krugh B, Garrad $\mathrm{RC}$, et al. P2Y(2) nucleotide receptor signaling in human monocytic cells: activation, desensitization and coupling to mitogen-activated protein kinases. J Cell Physiol. 2001;187(2):196-208.

41. Brunschweiger A, Muller CE. P2 receptors activated by uracil nucleotides an update. Curr Med Chem. 2006;13(3):289-312.

42. Chen $Y$, Corriden $R$, Inoue $Y$, Yip L, Hashiguchi N, Zinkernagel A, et al. ATP release guides neutrophil chemotaxis via $P 2 Y 2$ and $A 3$ receptors. Science. 2006;314(5806):1792-5.

43. Abbracchio MP, Burnstock G, Verkhratsky A, Zimmermann H. Purinergic signalling in the nervous system: an overview. Trends Neurosci. 2009;32(1): $19-29$.

44. North RA. Molecular physiology of P2X receptors. Physiol Rev. 2002;82(4): 1013-67.

45. Nihei OK, Savino W, Alves LA. Procedures to characterize and study P2Z/ P2X7 purinoceptor: flow cytometry as a promising practical, reliable tool. Mem Inst Oswaldo Cruz. 2000;95(3):415-28.

46. Surprenant A, Rassendren F, Kawashima E, North RA, Buell G. The cytolytic P2Z receptor for extracellular ATP identified as a $P 2 X$ receptor ( $P 2 X 7)$. Science. 1996;272(5262):735-8.

47. Humphreys BD, Dubyak GR. Modulation of P2X7 nucleotide receptor expression by pro- and anti-inflammatory stimuli in THP-1 monocytes. J Leukoc Biol. 1998;64(2):265-73.

48. Suh BC, Kim JS, Namgung U, Ha H, Kim KT. P2X7 nucleotide receptor mediation of membrane pore formation and superoxide generation in human promyelocytes and neutrophils. J Immunol. 2001;166(11):6754-63.

49. Burnstock G, Boeynaems JM. Purinergic signalling and immune cells. Purinergic Signal. 2014;10(4):529-64.

50. Alzola E, Perez-Etxebarria A, Kabre E, Fogarty DJ, Metioui M, Chaib N, et al. Activation by P2X7 agonists of two phospholipases A2 (PLA2) in ductal cells of rat submandibular gland. Coupling of the calcium-independent PLA2 with kallikrein secretion. J Biol Chem. 1998;273(46):30208-17.

51. Balboa MA, Balsinde J, Johnson CA, Dennis EA. Regulation of arachidonic acid mobilization in lipopolysaccharide-activated P388D(1) macrophages by adenosine triphosphate. J Biol Chem. 1999:274(51):36764-8.

52. Barbera-Cremades M, Baroja-Mazo A, Gomez Al, Machado F, Di VF, Pelegrin P. P2X7 receptor-stimulation causes fever via PGE2 and IL-1beta release. FASEB J. 2012;26(7):2951-62.

53. Panupinthu N, Rogers JT, Zhao L, Solano-Flores LP, Possmayer F, Sims SM, et al. P2X7 receptors on osteoblasts couple to production of 
lysophosphatidic acid: a signaling axis promoting osteogenesis. J Cell Biol. 2008;181(5):859-71.

54. Costa-Junior HM, Marques-da-Silva C, Vieira FS, Moncao-Ribeiro LC, Coutinho-Silva R. Lipid metabolism modulation by the P2X7 receptor in the immune system and during the course of infection: new insights into the old view. Purinergic Signal. 2011;7(4):381-92.

55. Peters-Golden M, Brock TG. 5-lipoxygenase and FLAP. Prostaglandins Leukot Essent Fatty Acids. 2003;69(2-3):99-109.

56. Ago H, Kanaoka Y, Irikura D, Lam BK, Shimamura T, Austen KF, et al. Crystal structure of a human membrane protein involved in cysteinyl leukotriene biosynthesis. Nature. 2007:448(7153):609-12.

57. Lam BK, Gagnon L, Austen KF, Soberman RJ. The mechanism of leukotriene B4 export from human polymorphonuclear leukocytes. J Biol Chem. 1990; 265(23):13438-41.

58. Leier I, Jedlitschky G, Buchholz U, Cole SP, Deeley RG, Keppler D. The MRP gene encodes an ATP-dependent export pump for leukotriene $\mathrm{C} 4$ and structurally related conjugates. J Biol Chem. 1994;269(45):27807-10.

59. Robbiani DF, Finch RA, Jager D, Muller WA, Sartorelli AC, Randolph GJ. The leukotriene C(4) transporter MRP1 regulates CCL19 (MIP-3beta, ELC)dependent mobilization of dendritic cells to lymph nodes. Cell. 2000;103(5):757-68.

60. Murphy RC, Gijon MA. Biosynthesis and metabolism of leukotrienes. Biochem J. 2007:405(3):379-95.

61. Peters-Golden M, Canetti C, Mancuso P, Coffey MJ. Leukotrienes: underappreciated mediators of innate immune responses. J Immunol. 2005; 174(2):589-94

62. Ricciotti E, FitzGerald GA. Prostaglandins and inflammation. Arterioscler Thromb Vasc Biol. 2011;31(5):986-1000.

63. Smith T, McCracken J, Shin YK, DeWitt D. Arachidonic acid and nonsteroidal anti-inflammatory drugs induce conformational changes in the human prostaglandin endoperoxide $\mathrm{H} 2$ synthase-2 (cyclooxygenase-2). J Biol Chem. 2000;275(51):40407-15.

64. Chandrasekharan NV, Dai H, Roos KL, Evanson NK, Tomsik J, Elton TS, et al. COX-3, a cyclooxygenase-1 variant inhibited by acetaminophen and other analgesic/antipyretic drugs: cloning, structure, and expression. Proc Natl Acad Sci U S A. 2002;99(21):13926-31.

65. Dubois RN, Abramson SB, Crofford L, Gupta RA, Simon LS, Van De Putte LB, et al. Cyclooxygenase in biology and disease. FASEB J. 1998;12(12):1063-73.

66. Scher JU, Pillinger MH. The anti-inflammatory effects of prostaglandins. J Investig Med. 2009;57(6):703-8.

67. Mukbel RM, Patten Jr C, Gibson K, Ghosh M, Petersen C, Jones DE, Macrophage killing of Leishmania amazonensis amastigotes requires both nitric oxide and superoxide. Am J Trop Med Hyg. 2007;76(4):669-75.

68. Miralles GD, Stoeckle MY, McDermott DF, Finkelman FD, Murray HW. Th1 and Th2 cell-associated cytokines in experimental visceral leishmaniasis. Infect Immun. 1994;62(3):1058-63.

69. Dey R, Majumder N, Bhattacharyya MS, Bhattacharjee S, Banerjee S, Roy S, et al. Induction of host protective Th1 immune response by chemokines in Leishmania donovani-infected BALB/c mice. Scand J Immunol. 2007;66(6): 671-83.

70. Castellano LR, Filho DC, Argiro L, Dessein H, Prata A, Dessein A, et al. Th1/ Th2 immune responses are associated with active cutaneous leishmaniasis and clinical cure is associated with strong interferon-gamma production. Hum Immunol. 2009;70(6):383-90.

71. Dudeck A, Suender CA, Kostka SL, von SE, Maurer M. Mast cells promote Th1 and Th17 responses by modulating dendritic cell maturation and function. Eur J Immunol. 2011:41(7):1883-93.

72. Katara GK, Ansari NA, Singh A, Ramesh V, Salotra P. Evidence for involvement of Th17 type responses in post kala azar dermal leishmaniasis (PKDL). PLoS Negl Trop Dis. 2012;6(6):e1703.

73. Coutinho-Silva R, Ojcius DM. Role of extracellular nucleotides in the immune response against intracellular bacteria and protozoan parasites. Microbes Infect. 2012;14(14):1271-7.

74. Marques-da-Silva C, Chaves MM, Chaves SP, Figliuolo VR, Meyer-Fernandes $\mathrm{JR}$, Corte-Real S, et al. Infection with Leishmania amazonensis upregulates purinergic receptor expression and induces host-cell susceptibility to UTPmediated apoptosis. Cell Microbiol. 2011;13(9):1410-28.

75. Chaves SP, Torres-Santos EC, Marques C, Figliuolo VR, Persechini PM, Coutinho-Silva R, et al. Modulation of P2X(7) purinergic receptor in macrophages by Leishmania amazonensis and its role in parasite elimination. Microbes Infect. 2009;11(10-11):842-9.
76. Serezani $\mathrm{CH}$, Perrela JH, Russo M, Peters-Golden M, Jancar S. Leukotrienes are essential for the control of Leishmania amazonensis infection and contribute to strain variation in susceptibility. J Immunol. 2006;177(5):3201-8.

77. Morato $\mathrm{Cl}$, da Silva IAJ, Borges AF, Dorta ML, Oliveira MA, Jancar S, et al. Essential role of leukotriene B4 on Leishmania (Viannia) braziliensis killing by human macrophages. Microbes Infect. 2014;16(11):945-53.

78. Tavares N, Afonso L, Suarez M, Ampuero M, Prates DB, Araujo-Santos T, et al. Degranulating neutrophils promote leukotriene B4 production by infected macrophages to kill Leishmania amazonensis parasites. J Immunol. 2016; 196(4):1865-73.

79. Vishwakarma P, Parmar N, Yadav PK, Chandrakar P, Kar S. 15d-Prostaglandin $J 2$ induced reactive oxygen species-mediated apoptosis during experimental visceral leishmaniasis. J Mol Med (Berl). 2016;94(6):695-710.

80. Hu Y, Fisette PL, Denlinger LC, Guadarrama AG, Sommer JA, Proctor RA, et al. Purinergic receptor modulation of lipopolysaccharide signaling and inducible nitric-oxide synthase expression in RAW 264.7 macrophages. J Biol Chem. 1998:273(42):27170-5.

81. Martel-Gallegos G, Casas-Pruneda G, Ortega-Ortega F, Sanchez-Armass S, Olivares-Reyes JA, Diebold B, et al. Oxidative stress induced by P2X7 receptor stimulation in murine macrophages is mediated by c-Src/Pyk2 and ERK1/2. Biochim Biophys Acta. 2013:1830(10):4650-9.

82. Steiner DR, Gonzalez NC, Wood JG. Leukotriene B(4) promotes reactive oxidant generation and leukocyte adherence during acute hypoxia. J Appl Physiol (1985 ). 2001;91(3):1160-7.

83. Woo CH, You HJ, Cho SH, Eom YW, Chun JS, Yoo YJ, et al. Leukotriene B(4) stimulates Rac-ERK cascade to generate reactive oxygen species that mediates chemotaxis. J Biol Chem. 2002;277(10):8572-8.

84. Luchtefeld M, Drexler H, Schieffer B. 5-Lipoxygenase is involved in the angiotensin II-induced NAD(P)H-oxidase activation. Biochem Biophys Res Commun. 2003;308(3):668-72.

85. Lee JW, Kim JH. Activation of the leukotriene B4 receptor 2-reactive oxygen species (BLT2-ROS) cascade following detachment confers anoikis resistance in prostate cancer cells. J Biol Chem. 2013;288(42):30054-63.

86. Lee W, Su KH, Lee GR. Leukotrienes induce the migration of Th17 cells. Immunol Cell Biol. 2015;93(5):472-9.

87. Sacramento LA, Cunha FQ, de Almeida RP, da Silva JS, Carregaro V. Protective role of 5-lipoxigenase during Leishmania infantum infection is associated with Th17 subset. Biomed Res Int. 2014:2014:264270.

88. Toda A, Terawaki K, Yamazaki S, Saeki K, Shimizu T, Yokomizo T. Attenuated Th1 induction by dendritic cells from mice deficient in the leukotriene B4 receptor 1. Biochimie. 2010;92(6):682-91.

89. Sullivan JA, Jankowska-Gan E, Shi L, Roenneburg D, Hegde S, Greenspan DS, et al. Differential requirement for P2X7R function in IL-17 dependent vs. IL17 independent cellular immune responses. Am J Transplant. 2014;14(7): $1512-22$

90. Killeen ME, Ferris L, Kupetsky EA, Falo Jr L, Mathers AR. Signaling through purinergic receptors for ATP induces human cutaneous innate and adaptive Th17 responses: implications in the pathogenesis of psoriasis. J Immunol. 2013:190(8):4324-36

91. Lonardoni MV, Barbieri CL, Russo M, Jancar S. Modulation of Leishmania (L.) amazonensis growth in cultured mouse macrophages by prostaglandins and platelet activating factor. Mediators Inflamm. 1994;3(2):137-41.

92. Barreto-de-Souza V, Pacheco GJ, Silva AR, Castro-Faria-Neto HC, Bozza PT, Saraiva EM, et al. Increased Leishmania replication in HIV-1-infected macrophages is mediated by tat protein through cyclooxygenase-2 expression and prostaglandin E2 synthesis. J Infect Dis. 2006;194(6):846-54.

93. Guimaraes ET, Santos LA, dos Ribeiro SR, Teixeira MM, dos Santos WL, Soares MB. Role of interleukin-4 and prostaglandin E2 in Leishmania amazonensis infection of BALB/c mice. Microbes Infect. 2006;8(5):1219-26.

94. Franca-Costa J, Van WJ, Boaventura VS, Luz NF, Malta-Santos H, Oliveira MC, et al. Arginase I, polyamine, and prostaglandin E2 pathways suppress the inflammatory response and contribute to diffuse cutaneous leishmaniasis. J Infect Dis. 2015;211(3):426-35.

95. Kabututu Z, Martin SK, Nozaki T, Kawazu S, Okada T, Munday CJ, et al. Prostaglandin production from arachidonic acid and evidence for a 9,11endoperoxide prostaglandin $\mathrm{H} 2$ reductase in Leishmania. Int J Parasitol. 2003;33(2):221-8.

96. Araujo-Santos T, Rodriguez NE, Moura-Pontes S, Dixt UG, Abanades DR, Bozza PT, et al. Role of prostaglandin F2alpha production in lipid bodies from Leishmania infantum chagasi: insights on virulence. J Infect Dis. 2014; 210(12):1951-61. 
97. Griffon B, Cillard J, Chevanne M, Morel I, Cillard P, Sergent O. Macrophageinduced inhibition of nitric oxide production in primary rat hepatocyte cultures via prostaglandin E2 release. Hepatology. 1998;28(5):1300-8.

98. Betz M, Fox BS. Prostaglandin E2 inhibits production of Th1 lymphokines but not of Th2 lymphokines. J Immunol. 1991;146(1):108-13.

99. Snijdewint FG, Kalinski P, Wierenga EA, Bos JD, Kapsenberg ML. Prostaglandin E2 differentially modulates cytokine secretion profiles of human T helper lymphocytes. J Immunol. 1993;150(12):5321-9.

100. Hilkens CM, Vermeulen $H$, van Neerven RJ, Snijdewint FG, Wierenga EA, Kapsenberg ML. Differential modulation of T helper type 1 (Th1) and T helper type 2 (Th2) cytokine secretion by prostaglandin E2 critically depends on interleukin-2. Eur J Immunol. 1995;25(1):59-63.

101. Saha A, Biswas A, Srivastav S, Mukherjee M, Das PK, Ukil A. Prostaglandin E2 negatively regulates the production of inflammatory cytokines/chemokines and IL-17 in visceral leishmaniasis. J Immunol. 2014;193(5):2330-9.

102. Peng Z, Fernandez P, Wilder T, Yee H, Chiriboga L, Chan ES, et al. Ecto-5'nucleotidase (CD73) -mediated extracellular adenosine production plays a critical role in hepatic fibrosis. FASEB J. 2008;22(7):2263-72.

103. Paletta-Silva R, Vieira DP, Vieira-Bernardo R, Majerowicz D, Gondim KC, Vannier-Santos MA, et al. Leishmania amazonensis: characterization of an ecto-3'-nucleotidase activity and its possible role in virulence. Exp Parasitol. 2011;129(3):277-83.

104. Rai AK, Thakur CP, Velpandian T, Sharma SK, Ghosh B, Mitra DK. High concentration of adenosine in human visceral leishmaniasis despite increased ADA and decreased CD73. Parasite Immunol. 2011;33(11):632-6.

105. Vieira DP, Paletta-Silva R, Saraiva EM, Lopes AH, Meyer-Fernandes JR. Leishmania chagasi: an ecto-3'-nucleotidase activity modulated by inorganic phosphate and its possible involvement in parasite-macrophage interaction. Exp Parasitol. 2011;127(3):702-7.

106. Leite PM, Gomes RS, Figueiredo AB, Serafim TD, Tafuri WL, de Souza CC, et al. Ecto-nucleotidase activities of promastigotes from Leishmania (Viannia) braziliensis relates to parasite infectivity and disease clinical outcome. PLoS Negl Trop Dis. 2012;6(10), e1850.

107. Pinheiro CM, Martins-Duarte ES, Ferraro RB, Fonseca de Souza AL, Gomes MT, Lopes AH, et al. Leishmania amazonensis: Biological and biochemical characterization of ecto-nucleoside triphosphate diphosphohydrolase activities. Exp Parasitol. 2006;114(1):16-25.

108. Giarola NL, Silveira TS, Inacio JD, Vieira LP, Almeida-Amaral EE, MeyerFernandes JR. Leishmania amazonensis: Increase in ecto-ATPase activity and parasite burden of vinblastine-resistant protozoa. Exp Parasitol. 2014;146:25-33.

109. Gomes RS, de Carvalho LC, de S V, Fietto JL, Afonso LC. E-NTPDase (ecto-nucleoside triphosphate diphosphohydrolase) of Leishmania amazonensis inhibits macrophage activation. Microbes Infect. 2015;17(4): 295-303.

110. Berredo-Pinho M, Peres-Sampaio CE, Chrispim PP, Belmont-Firpo R, Lemos AP, Martiny A, et al. A Mg-dependent ecto-ATPase in Leishmania amazonensis and its possible role in adenosine acquisition and virulence. Arch Biochem Biophys. 2001;391(1):16-24.

111. Figueiredo AB, Serafim TD, Marques-da-Silva EA, Meyer-Fernandes JR, Afonso LC. Leishmania amazonensis impairs DC function by inhibiting CD40 expression via A2B adenosine receptor activation. Eur J Immunol. 2012;42(5): 1203-15.

112. Cadieux JS, Leclerc P, St-Onge M, Dussault AA, Laflamme C, Picard S, et al. Potentiation of neutrophil cyclooxygenase- 2 by adenosine: an early antiinflammatory signal. J Cell Sci. 2005;118(Pt 7):1437-47.

113. Pouliot M, Fiset ME, Masse M, Naccache PH, Borgeat P. Adenosine upregulates cyclooxygenase-2 in human granulocytes: impact on the balance of eicosanoid generation. J Immunol. 2002;169(9):5279-86.

114. Mackenzie KF, Clark K, Naqvi S, McGuire VA, Noehren G, Kristariyanto Y, et al. PGE(2) induces macrophage IL-10 production and a regulatory-like phenotype via a protein kinase A-SIK-CRTC3 pathway. J Immunol. 2013; 190(2):565-77.

115. Nemeth ZH, Lutz CS, Csoka B, Deitch EA, Leibovich SJ, Gause WC, et al. Adenosine augments IL-10 production by macrophages through an A2B receptor-mediated posttranscriptional mechanism. J Immunol. 2005;175(12): 8260-70.

116. Hasko G, Kuhel DG, Chen JF, Schwarzschild MA, Deitch EA, Mabley JG, et al. Adenosine inhibits IL-12 and TNF-[alpha] production via adenosine A2a receptor-dependent and independent mechanisms. FASEB J. 2000;14(13): 2065-74.
117. Vassiliou E, Jing H, Ganea D. Prostaglandin E2 inhibits TNF production in murine bone marrow-derived dendritic cells. Cell Immunol. 2003;223(2):120-32.

118. Flamand N, Boudreault S, Picard S, Austin M, Surette ME, Plante H, et al. Adenosine, a potent natural suppressor of arachidonic acid release and leukotriene biosynthesis in human neutrophils. Am J Respir Crit Care Med. 2000;161 (2 Pt 2):S88-94

119. Krump E, Picard S, Mancini J, Borgeat P. Suppression of leukotriene B4 biosynthesis by endogenous adenosine in ligand-activated human neutrophils. J Exp Med. 1997;186(8):1401-6.

120. Surette ME, Krump E, Picard S, Borgeat P. Activation of leukotriene synthesis in human neutrophils by exogenous arachidonic acid: inhibition by adenosine $\mathrm{A}(2 \mathrm{a})$ receptor agonists and crucial role of autocrine activation by leukotriene B(4). Mol Pharmacol. 1999;56(5):1055-62.

121. Krump E, Lemay G, Borgeat P. Adenosine A2 receptor-induced inhibition of leukotriene B4 synthesis in whole blood ex vivo. Br J Pharmacol. 1996; 117(8):1639-44.

122. Peters NC, Sacks DL. The impact of vector-mediated neutrophil recruitment on cutaneous leishmaniasis. Cell Microbiol. 2009;11(9):1290-6.

123. Laufs $\mathrm{H}$, Muller K, Fleischer J, Reiling N, Jahnke N, Jensenius JC, et al. Intracellular survival of Leishmania major in neutrophil granulocytes after uptake in the absence of heat-labile serum factors. Infect Immun. 2002; 70(2):826-35.

124. Ribeiro-Gomes FL, Peters NC, Debrabant A, Sacks DL. Efficient capture of infected neutrophils by dendritic cells in the skin inhibits the early antiLeishmania response. PLoS Pathog. 2012;8(2):e1002536.

125. Novais FO, Santiago RC, Bafica A, Khouri R, Afonso L, Borges VM, et al. Neutrophils and macrophages cooperate in host resistance against Leishmania braziliensis infection. J Immunol. 2009;183(12):8088-98.

126. Mahamed DA, Mills JH, Egan CE, Denkers EY, Bynoe MS. CD73-generated adenosine facilitates Toxoplasma gondii differentiation to long-lived tissue cysts in the central nervous system. Proc Natl Acad Sci U S A. 2012;109(40): $16312-7$.

127. Thammavongsa V, Kern JW, Missiakas DM, Schneewind O. Staphylococcus aureus synthesizes adenosine to escape host immune responses. J Exp Med. 2009:206(11):2417-27.

128. Firon A, Dinis M, Raynal B, Poyart C, Trieu-Cuot P, Kaminski PA. Extracellular nucleotide catabolism by the Group B Streptococcus ectonucleotidase NudP increases bacterial survival in blood. J Biol Chem. 2014;289(9):5479-89.

129. Belkaid Y, Kamhawi S, Modi G, Valenzuela J, Noben-Trauth N, Rowton E, et al. Development of a natural model of cutaneous leishmaniasis: powerful effects of vector saliva and saliva preexposure on the long-term outcome of Leishmania major infection in the mouse ear dermis. J Exp Med. 1998; 188(10):1941-53.

130. Kamhawi S. The biological and immunomodulatory properties of sand fly saliva and its role in the establishment of Leishmania infections. Microbes Infect. 2000;2(14):1765-73.

131. Hall LR, Titus RG. Sand fly vector saliva selectively modulates macrophage functions that inhibit killing of Leishmania major and nitric oxide production. J Immunol. 1995;155(7):3501-6.

132. Prates DB, Araujo-Santos T, Luz NF, Andrade BB, Franca-Costa J, Afonso L, et al. Lutzomyia longipalpis saliva drives apoptosis and enhances parasite burden in neutrophils. J Leukoc Biol. 2011;90(3):575-82

133. Charlab R, Valenzuela JG, Rowton ED, Ribeiro JM. Toward an understanding of the biochemical and pharmacological complexity of the saliva of a hematophagous sand fly Lutzomyia longipalpis. Proc Natl Acad Sci USA. 1999;96(26):15155-60.

134. de Moura TR, Oliveira F, Rodrigues GC, Carneiro MW, Fukutani KF, Novais $\mathrm{FO}$, et al. Immunity to Lutzomyia intermedia saliva modulates the inflammatory environment induced by Leishmania braziliensis. PLoS Negl Trop Dis. 2010;4(6):e712.

135. Katz O, Waitumbi JN, Zer R, Warburg A. Adenosine, AMP, and protein phosphatase activity in sandfly saliva. Am J Trop Med Hyg. 2000;62(1):145-50

136. Carregaro V, Ribeiro JM, Valenzuela JG, Souza-Junior DL, Costa DL, Oliveira CJ, et al. Nucleosides present on phlebotomine saliva induce immunossuppression and promote the infection establishment. PLoS Negl Trop Dis. 2015;9(4):e0003600.

137. Atayde VD, Aslan H, Townsend S, Hassani K, Kamhawi S, Olivier M. Exosome secretion by the parasitic protozoan leishmania within the sand fly midgut. Cell Rep. 2015;13(5):957-67. 
138. Araujo-Santos T, Prates DB, Andrade BB, Nascimento DO, Clarencio J, Entringer PF, et al. Lutzomyia longipalpis saliva triggers lipid body formation and prostaglandin E(2) production in murine macrophages. PLoS Negl Trop Dis. 2010:4(11):e873.

139. Araujo-Santos T, Prates DB, Franca-Costa J, Luz NF, Andrade BB, Miranda JC, et al. Prostaglandin E2/leukotriene B4 balance induced by Lutzomyia longipalpis saliva favors Leishmania infantum infection. Parasit Vectors. 2014; 7:601.

Submit your next manuscript to BioMed Central and we will help you at every step:

- We accept pre-submission inquiries

- Our selector tool helps you to find the most relevant journal

- We provide round the clock customer support

- Convenient online submission

- Thorough peer review

- Inclusion in PubMed and all major indexing services

- Maximum visibility for your research

Submit your manuscript at www.biomedcentral.com/submit 